\title{
MARBLE THRONES IN BUKHARA AND SAMARKAND FROM THE TIMURID ERA TO THE LATE MANGHIT ERA (AN ARTISTIC ARCHAEOLOGICAL STUDY)
}

\author{
Mohamed, $\mathrm{H}$.
}

Islamic Archaeology dept., Faculty of Archaeology, Cairo Univ., Cairo, Egypt

E-mail address: hadhood_hs85@yahoo.com

\begin{tabular}{|c|c|}
\hline Article info. & EJARS - Vol. 11 (1) - June. 2021: 101-114 \\
\hline Article history: & Abstract: \\
\hline Received: 6-5-2020 & Central Asia is one of the most important regions of the Muslim \\
\hline Accepted: $23-4-2021$ & world historically, culturally, and architecturally. It houses many \\
\hline Doi: $10.21608 /$ ejars.2021.179500 & $\begin{array}{l}\text { architectural monuments throughout Islamic history, such as the } \\
\text { palaces whose reception halls contain thrones of the coronation } \\
\text { of princes. The present study aims to highlight the remaining marble } \\
\text { thrones in Bukhara and Samarkand from the Timurid Era to the } \\
\text { Late Manghit Era. It examines the development of their shapes }\end{array}$ \\
\hline $\begin{array}{l}\text { Keywords: } \\
\text { Throne, Kök Tash }\end{array}$ & $\begin{array}{l}\text { and decorative elements based on two models, i.e. the Throne of } \\
\text { Kök Tash in Samarkand citadel and the Throne of Bukhara in Ark. } \\
\text { To document and reaister these thrones, the study adopted the }\end{array}$ \\
\hline Bukhara & analytical descriptive approach. It identified their raw materials, \\
\hline Samarkand & manufacturing, decoration, decorative elements, location in the \\
\hline Ark & palaces, models, and shapes based on the remaining models. The \\
\hline Marble & $\begin{array}{l}\text { ompared these models to counterparts in the paintings of } \\
\text { ntral Asian manuscripts. It concluded with a set of imp- }\end{array}$ \\
\hline Central Asia & ortant results in the field of Islamic archaeology in Central Asia. \\
\hline
\end{tabular}

\section{Introduction}

The throne is a manifestation of greatness, grandeur, and luxury for rulers, including kings, sultans, and princes from time immemorial to the Islamic era. It was employed for coronation and legitimization of rule. Architecturally and artistically, a throne is a basic item in the reception halls of the royal palaces. Central Asia is one of the most important areas of the Muslim world. It was ruled by many Muslim dynasties from the Islamic conquest to the Russian invasion in $1339 \mathrm{AH}$. / 1920 AD. Accordingly, Central Asia is rich in the various architectural establishments, especially palaces that contain reception halls and thrones called "Takht", i.e. a throne in the front part of the palace [1]. However, no information is available about the shape of thrones in
Central Asia in the early Islamic era. Their oldest model is the marble throne dated back to the Timurid dynasty, known as "Kök Tash". No thrones remained from the Shaybanid (906-1006 AH. / 1500-1597 AD.) and Ashtarkhanid dynasties (10061157 AH. / 1597-1744 AD.). In the Manghit era (1160-1339 AH. / 1747-1920 AD.), marble and wooden thrones were introduced. Sela [2] examined Kök Tash historically. He tracked its history in the Timurid historical resources and its relation to the historical events in Central Asia. Moreover, Sela reported the writings of travelers who visited the region in the $13^{\text {th }} \mathrm{H}$. / $19^{\text {th }} \mathrm{G}$. century. Despite its importance and the abundant information it provided, Sela did not highly consider the artistic aspect of the throne and did not investigate the throne of Bukhara in 
Ark. The present study investigates the marble thrones and tracks their history and the development of shapes and decoration by examining two remaining models, i.e. the throne of Kök Tash in Samarkand citadel to complete its artistic study and the throne of Bukhara in Ark. It examines the throne of Bukhara historically, archaeologically, and artistically. Moreover, it explores the development of the shapes of thrones in this era. The study relies on the paintings of manuscripts in Central Asia from the Timurid to the Late Shaybanid dynasties to identify the models and evolving shapes of these thrones. Furthermore, it compares them with the remaining models, especially the marble ones. Because of being heavy, large, and difficult to move, marble helped keep these thrones. On the contrary, wood was prone to damage and deterioration due to being easy to burn, move, or steal. The study made use of the analytical descriptive approach to document and register these thrones. It identified their raw materials, manufacturing, decoration, models, decorative elements, location in the palaces, and shapes based on the remaining models. It also compared these thrones to the paintings in the manuscripts of Central Asia.

\section{Descriptive Study \\ 2.1. Kök Saray Palace}

It is located in the old citadel of Samarkand "Orda". Baber describes the palace established by Amir Timur in Samarkand as four floors high. It is known as "Kök Saray" similar to the palace established in Kesh known as "Ak Saray" or the "White Palace". It is an important palace because it contains the famous stone "Kök Tash" used by the kings of Bukhara since the era of Amir Timur. Baber reports that each prince of the Timurid dynasty was coronated in "Kök Saray"[3].

\subsubsection{Reception Hall}

The marble throne "Kök Tash" lies in the reception hall of the palace. It is a rectangular courtyard surrounded by three aisles, covered with a wooden ceiling, and based on engraved wooden columns. In the front part of the yard, there is a niche with a pointed arch and a squinch with rows of stalactites. "Kök Tash" throne is positioned in the front part of the niche opposite to the reception hall that was used to hold the occasions and celebrations of khans and princes.

\subsubsection{History of the Throne}

A legend arose that stone had fallen from the sky and would not allow one of genuine descent to approach it. In 1134 AH. / 1722 AD., when a rebellion against Abul Feiz Khan broke out, people complained that he had never fulfilled the formality of sitting on the Kök Tash. The rebels proclaimed in his place Rejen Khan [3]. When Omar Khan seized power in Bukhara, he sent to the ruler of Samarkand to surrender. However, the arrival of prince Nasralla to Samarkand made it impossible as he was crowned on Kök Tash[4]. Kök Tash is a two-syllable word meaning green or grey stone. It is a dark grey marble stone used as a throne since the reign of Amir Timur. During the coronation, the royal households sit the new prince of Bukhara on a carpet on it. It was narrated that this throne was in the reception hall of Amir Timur. It was later moved inside the palace of Khan inside Samarkand Citadel. When the Russians took the city, they transferred the palace into an ammunition depot of artillery and a hospital for the army forces [5].

\subsubsection{The Throne of Samarkand}

It is a rectangular whitish-grey marble. It measures $(3 \mathrm{~m} \times 121 \mathrm{~cm})$. It is based on a base of brick wider than the main bench. The four sides are decorated with a frame containing modified floral motifs (islimi) implemented as high relief. In the corners on the bench, there are four compact columns of a base, a body of a three-quarter circle decorated with high relief helical shapes topped with a crown. The back of the throne is a fivelobed arch of marble without decorations, fig. (1) 


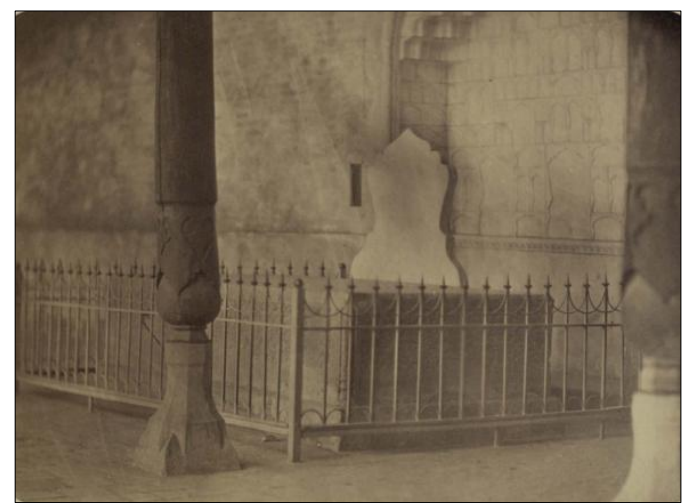

Figure (1) Shows a photo of the throne of Kök Tash in Samarkand (After, Turkistan Album, 1871-1872)

\subsection{The reception hall in Ark Buk- hara}

The Kornish-Khana (reception hall) is the oldest remaining building in Ark. It is a courtyard surrounded by a riwaq based on wooden columns from three directions. The fourth direction contains the entrance. In the front part of the reception hall, a throne is based on four engraved columns made of the marble of Nurata [6], fig. (2)

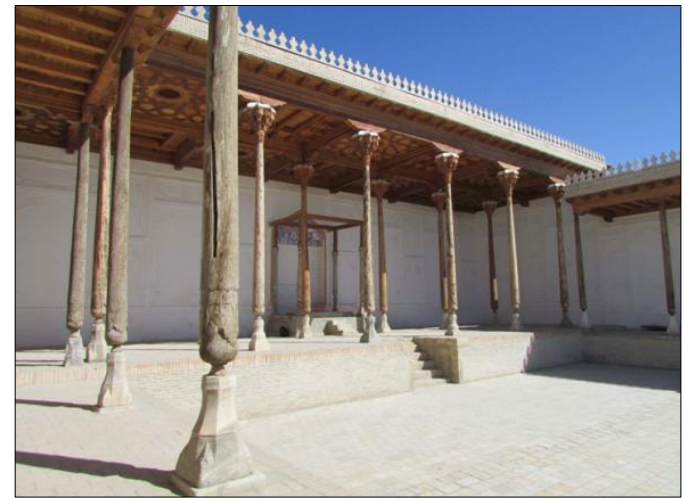

Figure (2) Shows the reception hall of Ark Bukhara

\subsubsection{The throne of Bukhara}

It is made of grey marble. It is rectangular and consists of two benches. The lower bench is larger, wider, and higher. It measures $(3.90 \mathrm{~m} \times 1.90 \mathrm{~m})$. The sides of the bench are decorated with a wide frame divided into three horizontal sections. The middle section is the largest and it is decorated with floral motifs implemented in high relief of half-palmettes forming oval shapes like bukhariyyas and containing flowers in the middle. The sides of the bukhariyyas are related to a rhombus intermediate with a small rose. The rhombus links the flowers together and the half flowers above and below it. Also, the upper and lower sections take the form of a narrow frame decorated with modified floral motifs made of halfpalmettes forming wavy stems from which smaller half-palmettes emerge. The upper sides of the thrones end with two rows of stalactites, fig. (3).

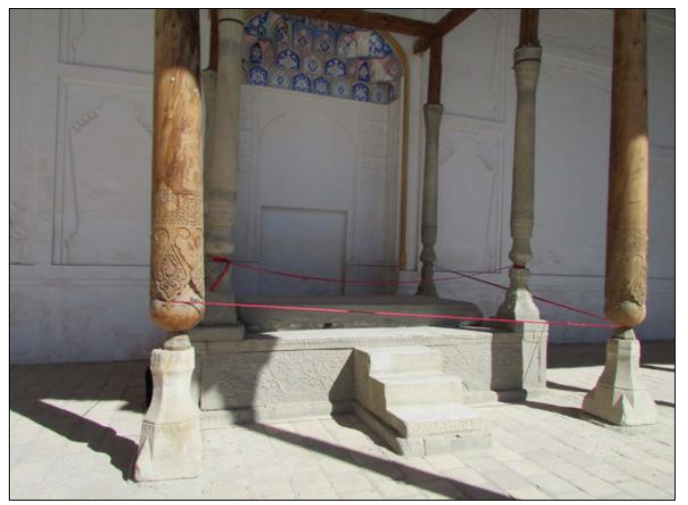

Figure (3) Shows the marble throne in the reception hall of Ark Bukhara

The sides of the upper bench $(2.98 \mathrm{~m} \times$ $1.50 \mathrm{~m}$ ) are decorated with two horizontal frames. While the lower frame is decorated with a row of stalactites, the upper frame is decorated with rectangular frames of writing with lobbed sides interspersed with Persian inscriptions implemented in Nastaliq script that read

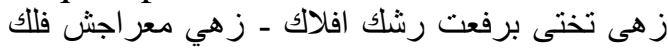

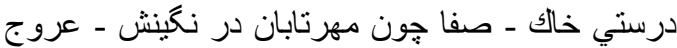

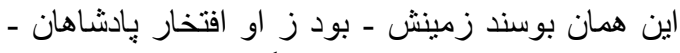

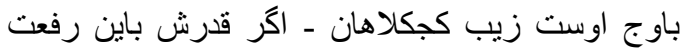

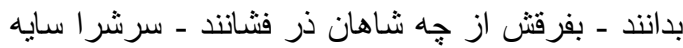

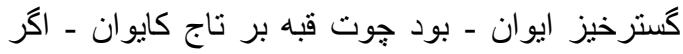

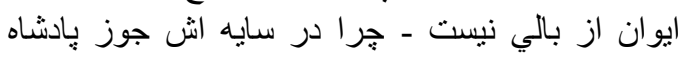

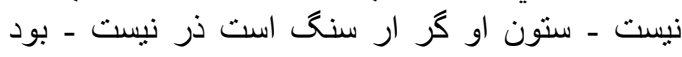

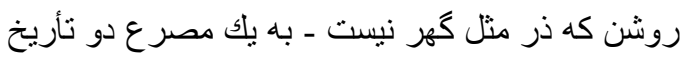

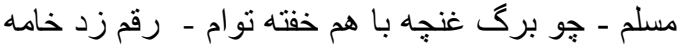

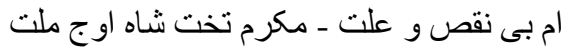

They are separated by four-lobed medallions interspersed with floral motifs implemented in high relief and containing four interrelated small roses to form a rhombus. From these roses, four halfpalmettes emerge. Moreover, the surface of the bench is surrounded by a rectangular frame decorated with floral motifs implemented in high relief, fig. (4). 


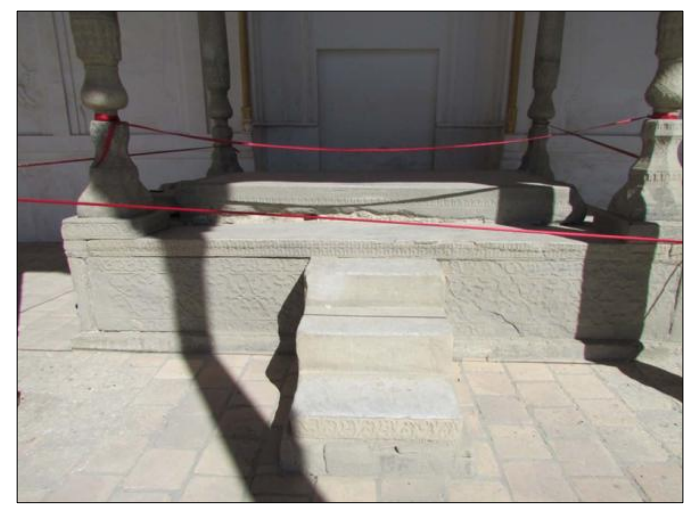

Figure (4) Shows the mastaba (bench) and staircase of the throne

The translation of the inscription: "What a throne that transcends spheres- The sphere collapsed from orbit-Its purity shines in essence-It kisses (touches) the ground while rotating-Kings feel proud of it- In its highness is a beauty of the arrogant-If they know that it has such magnitude- They will understand why kings scatter gold on its parts. The iwan spread shadow on its head-A quarter of the dome shade a crown resembles an iwan-If the iwan was not made of rubble- Then, why not have the king's nut fruit?- It is not gold if its pillar is of stone- It sparkles, so gold is not as a jewel- Two dates are inserted of one masraa- Their fold resembles a bud-My pen wrote without a decrease or a causeThat the glory of the king's throne is in the elevation of the nation".

\subsubsection{Staircase}

In front of the throne, there is a marble staircase of $65 \mathrm{~cm}$ high on a stone base. It consists of three steps, and each step is $75 \mathrm{~cm}$ wide. The staircase is plain except for the sides that continue the same design implemented on the sides of the bench. The façade of the first step is decorated with a narrow frame interspersed with floral motifs made of halfpalmettes forming a wavy stem from which smaller half-palmettes emerge.

\subsubsection{Column Bases}

The first bench is topped by four marble columns based on square bases that measure $(50 \times 50 \mathrm{~cm})$. The corners are decorated with floral motifs implemented in high relief. These motifs are made of two wavy stems. While one of them is made of flowers, the other contains halfpalmettes. The bases of the four columns are similar. They are $75 \mathrm{~cm}$ high. Each column has a square base that narrows and turns into a polygon as it moves up. The base is divided into horizontal sections. The first section is decorated with two frames. The lower frame is adorned with a row of machicoulises in the form of up and down leaves. Moreover, the upper frame is interspersed with hexagonal geometric figures encompassing a sixpoint star. Six-petal small roses decorate them from inside. The second section is ribbed and decorated with a row of stalactites topped with ribbed, fractures, and helical shapes. The third section comprises two frames. While the lower frame is decorated with a raw of machicoulises in the form of triple up and down leaves, the upper frame is decorated with interrelated geometric shapes. The fourth section is adorned with a row of stalactites. In the upper and lower parts, these sections are separated by a narrow frame decorated with geometric shapes of triangles, fig. (5).

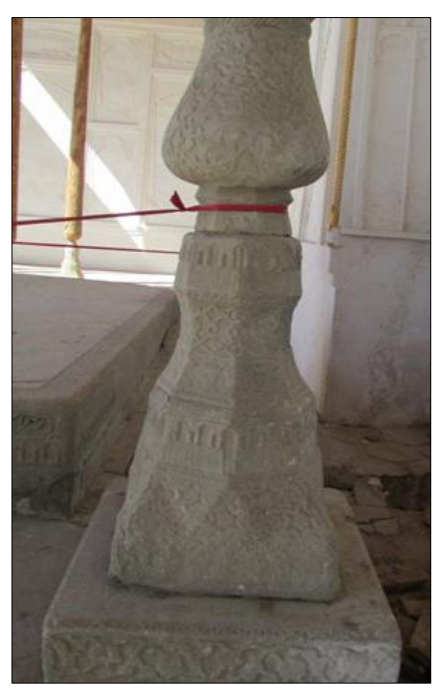

Figure (5) Shows a base of one of the throne's columns

\subsubsection{Columns}

The throne has four columns that are similar in form and decoration and different in inscription. The back columns facing the wall are similar, but they differ from the front columns facing the courtyard. 
*) Front columns

The right column is divided into various sections. The lower section begins with a pear-like shape on a ribbed base, which is decorated with complex and interrelated geometric shapes in high relief. The upper part of the pear-like shape is a narrow frame decorated with broken geometric shapes. The middle section is cylindrical. It begins with three rows of stalactites based on a narrow frame of zigzag shapes in high relief. In the beginning, it has rectangular frames of writing with lobbed sides interspersed with Persian inscriptions implemented in Nastaliq ش ون جود را بفر سنى -زرشك " script and read "ايرم ستن كه آيد كر ان سنى by four-lobed medallions interspersed with floral motifs implemented in high relief and containing four interrelated triple-leaves to form a rhombus occupied with a quadrilateral small rose of pointed petals. Triangles decorated with the same former shape occupy the space separating the medallions, fig. (6).

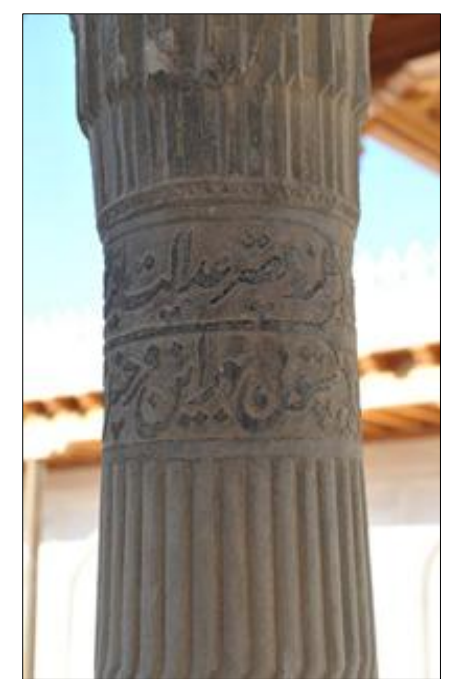

Figure (6) Shows one of the front column of the throne of Bukhara

The body is decorated with geometric shapes of right ribs that encompass helical ribs in high relief. It ends with two rows of rectangular frames of writing with lobbed sides interspersed with Persian inscriptions in Nastaliq script. While the

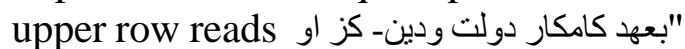
"قصر عدالت يافت تزيين" the lower row reads "مهيا ساخت استاد هنرور - ستونى بهر اين فرخنده هنظر تزئر"
Both rows are separated by medallions of concave sides interspersed with floral motifs of four interrelated small roses to form a rhombus. A narrow frame encompasses the upper part of the frames. It is decorated with zigzag geometric shapes (triangles) in high relief. The column ends with a stalactite capital of five rows that become broader as they move up. The translation of the inscription: "Envy Emad Arm where heavy stones are brought- in the reign of Nasir-u-dawla wa-ddin-That decorates the Palace of Justice-Made by alostaz wa-saheb-ul-funon-For this blessed event, it became the throne".

The left column resembles the general form and decorations of the former one but differs in inscriptions. The cylindrical body begins with a row of rectangular frames of writing with lobbed sides interspersed with Persian inscriptions in Nastaliq script that read - بود تأريخ أو بى كسر ونقصان "دو سرو بايدار يك كلستان" The body ends with two rows of rectangular frames of writing with lobbed sides interspersed with Persian inscriptions in Nastaliq script. While the

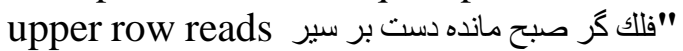

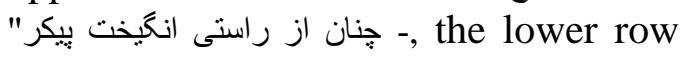

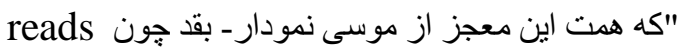

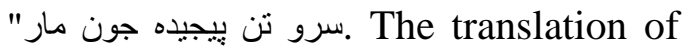
the inscription: "Its date had neither a decimal nor decrease- two cypresses form a garden- if the orbit ceases till the morning- like the shiver of the body in reality- the aim of this miracle of Moses will be clear-in the stature of cypress and a soft body like a snake".

*) Back Columns

The left column: The body is divided into various sections. The lower section begins with a pear-like shape on a ribbed base, which is decorated with modified floral motifs of stems ending with halfpalmettes and leaves in high relief. The pear-like shape ends, from the top, with a narrow frame decorated with helical shapes. The middle section is cylindrical. It begins with three rows of stalactites based on a narrow frame of zigzag shapes in high relief. In the beginning, it has rectangular frames of writing with lobbed 
sides interspersed with Persian inscriptions implemented in Nastaliq script and read "باوج رونق طوبى مثالى- جنين زيبا ستون افراخت "قامت . They are separated by four-lobed medallions interspersed with floral motifs implemented in high relief and containing four interrelated triple-leaves to form a rhombus. The space separating the medallions has the same design. Moreover, the frames of writing are encompassed by zigzag geometric shapes that form triangles in high relief. The body is decorated with modified floral motifs of interrelated stems that end with half-palmettes, buds, feathered $s a z$ leaves, triple leaves, flowers, and six-petal small roses in high relief. The cylindrical body ends with two rows of rectangular frames of writing with lobbed sides interspersed with Persian inscriptions in Nastaliq script. While the upper row reads محيط دانش وصاحب داحبs "كمالى-بحكم شاه دار الملك توران" the lower row

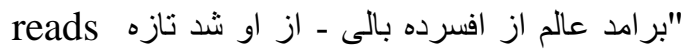
"قصر بخت واقبال" They are separated by quadrilateral lobbed medallions interspersed with floral motifs in high relief of four connected triple-leaves to form a rhombus. The space separating the medallions has the same design. Moreover, the frames of writing are encompassed by zigzag geometric shapes that form triangles in high relief. The column ends with an arched column of five rows. It becomes broader as it moves up, fig. (7).

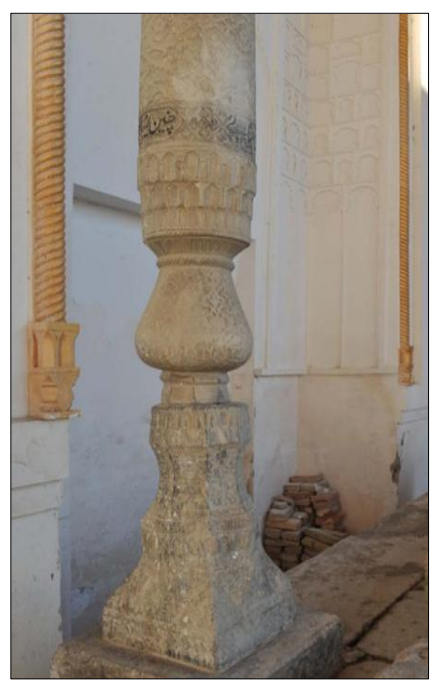

Figure (7) Shows one of the back columns of the throne of Bukhara
The translation of the inscription: "It became at the top of glamor and an example of joy- The stature of columns became high in such a beauty-mohet-ul-elm and saheb-ul-kamal-in the rule of the kingdom of Turan- The world was made of old scrap- The palace of luck and attendance was restored.

The right column: resembles the general form and decorations of the former one but differs in inscriptions. The cylindrical body begins with a row of rectangular frames of writing with lobbed sides interspersed with Persian inscriptions in "ز صاف باده تأريخش Nastaliq script that read

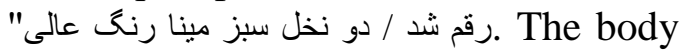
ends with two rows of rectangular frames of writing with lobbed sides interspersed with Persian inscriptions in Nastaliq script. The upper row reads دو شمشاد يست "سرد اندام موزون / ز باغستان صنع لايز الى" whereas "ز فيض راستيها سر كثيده

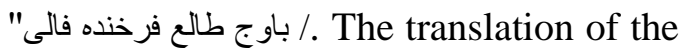
inscription: Its date was written by pure wine-Two high greenish palm trees- Two cold willows of thin stature-from a garden that Allah (the Eternal) created-From the excess of truth drink-for good luck.

\subsubsection{The ceiling of the throne}

The Throne of Bukhara had a colorful and engraved wooden ceiling. Unfortunately, this ceiling was missed and is currently replaced with a modern ceiling. It was modeled after the colorful wooden ceiling in Bukhara in the $10^{\text {th }} \mathrm{H}$. $/ 16^{\text {th }}$ G. century.

\section{Analytical Study}

The analytical study covers the marble thrones' location inside the palaces and models. It compares these models with the paintings of manuscripts and identifies their origin, raw material, manufacturing, and decorations. It also examines the deco-rative items, including floral and geometric motifs and reads and analyzes the inscriptions in terms of form and content.

\subsection{Location of the thrones}

The thrones were often in the front part of the niche of the reception hall's main 
Iwan in the royal palaces dedicated for the occasions and celebrations of the khans and princes in Bukhara and Samarkand (from the Timurid to the Late Manghit eras). Such things extended to the khans' palaces in Khiva and Kokand in the $13^{\text {th }} \mathrm{H}$. / $19^{\text {th }} \mathrm{G}$. century. The inscriptions of the marble throne in Bukhara describe the throne and its location in the iwan of Justice Palace. Additionally, the thrones were also depicted inside palaces and buildings, in the open air, in the gardens, on the banks, or inside tents.

\subsection{Model of the thrones}

According to the models under study, the remaining thrones in Bukhara and Samarkand are categorized in terms of form into two main models.

\subsubsection{The $1^{\text {st }}$ model (the mastaba)}

This model is a bench-like throne. It is a rectangular marble block with composite side columns. To sit on the throne, a person uses a staircase. The Throne of Kök Tash in Samarkand dating back to the Timurid era represents this model. The paintings of the manuscripts illustrate that this model existed in Central Asia from the early $10^{\text {th }} \mathrm{H}$. / $16^{\text {th }} \mathrm{G}$. century to the second half of the $11^{\text {th }} \mathrm{H}$. / $17^{\text {th }} \mathrm{G}$. century. This model took many forms, as follows: *) The square throne: This model was represented by the school of Tashkent in the early $10^{\text {th }} \mathrm{H}$. $/ 16^{\text {th }} \mathrm{G}$. century. It took the form of a simple high square throne on four legs. It appears in a painting entitled "Kashifi Presents his Manuscript to the Minister", Manuscript of Anwari Sohil by Hussein ibn Ali Alfayd "Kashifi" in 926 AH. / 1520 AD., Tashkent. This simple model resembles a painting entitled "Mani Presents his Paintings to King Buhram Gur" by Ali Shir Nawai (927-928 AH. / 1521-1522 AD.), Tashkent [7]. The King Buhram was depicted sitting down on a throne (a square block) on four short legs, and a two-step staircase was in front. The surface and sides of the throne were decorated with floral motifs and bukhariyyas. This throne almost resembles the wellknown throne of Kök Tash in Samarkand, fig. (8).

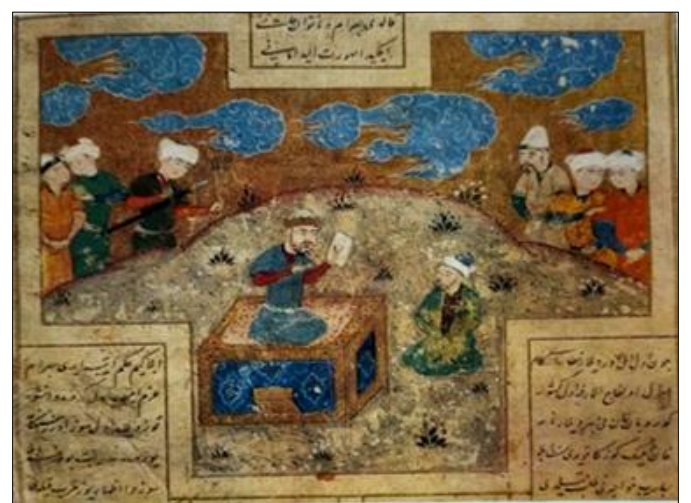

Figure (8) Shows a painting entitled "Mani Presents his paintings to king Buhram-Gur" (After Пугаченкова, Миниатюры Средней Азии, 1979)

In the second half of the $10^{\text {th }} \mathrm{H}$. / $16^{\text {th }} \mathrm{G}$. century, this simple model evolved. Thrones became higher, and the edge was surrounded -from three sides- by a balustrade whose legs end with pomegranate-like shapes, and the fourth (front) side is incomplete. Moreover, a small stand or footrest with animal legs was in front of the throne. The sides were decorated with geometric shapes. This model appears in a painting entitled "A Minister Seeks Forgiveness for Young Thieves", Manuscript of Bustan Saadi, 963-974 AH./ 1556-1567 AD., Bukhara [7]. *) The rectangular throne: It is represented by the high thrones of the schools of Bukhara and Samarkand in the first half of the $10^{\text {th }} \mathrm{H} . / 16^{\text {th }} \mathrm{G}$. century. It took the form of a rectangular throne based on medium height legs. While the sides were decorated with geometric shapes, the edge was surrounded- from three sides- by a balustrade whose legs end with pomegranate-like shapes, and the fourth (front) side was open completely. This model appears in a painting entitled "Genghis Khan Receives his Sons on the Banks of Serdaria River" by Masoud ibn Osman Kuhistani, Manuscript of the History of Abu Alkhair Khan in 946 AH. / 1540 AD., Samarkand. It resembles a painting entitled "Joseph in the Garden of Zulekha" by Jami, Manuscript of Joseph and Zulekha (a private collection) in $957 \mathrm{AH}$. / 1550 AD., Bukhara [7]. However, they differ in the long legs and the front incomplete side of the balustrade, fig. (9). 


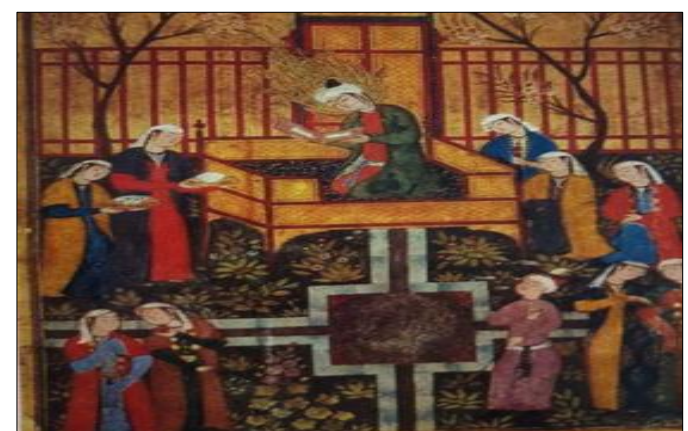

Figure (9) Shows painting entitled "Joseph in the Garden of Zulekha" (After Пугаченкова, Миниатюры Средней Азии, 1979)

This model also appears in another painting entitled "Timur's Reception", Manuscript of Timur Nama, Abdalla Hatifi, 975 AH. / 1568 AD. Timur is depicted sitting down on a throne of this model and resting on its long legs. The front part of the balustrade is completely open, and a rectangular footrest is in front of the throne [8]. *) The hexagonal throne: This model was implemented by the schools of Bukhara and Samarkand from the mid- $10^{\text {th }} \mathrm{H}$. / $16^{\text {th }} \mathrm{G}$. to the mid- $11^{\text {th }} \mathrm{H}$. / $17^{\text {th }}$ century. It is a hexagonal throne based on animal legs, and the sides are decorated with modified floral motifs. It is depicted in a painting entitled "Genghis Khan Offers a Banquet for the Nobles in his Tent in Organ" by Masoud ibn Osman Kuhistani, Manuscript of the History of Abu Alkhair Khan in 946 AH. / 1540 AD. [7], fig. (10).

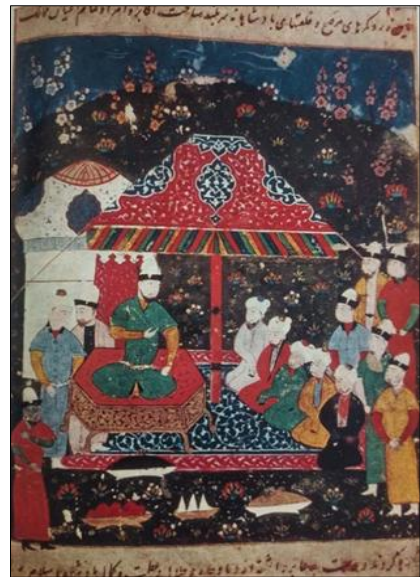

Figure (10) Shows a painting entitled "Genghis Khan offers a banquet for the nobles in his tent in organ" (After Пугач-енкова, Миниатюры Средней Азии, 1979)

This form continued in the early $11^{\text {th }} \mathrm{H}$. / $17^{\text {th }} \mathrm{G}$. century. It appears in a painting entitled "Celebrations of Timur in the Suburbs of Samarkand" by Sharaf Eldin
Ali Yazdi of the Manuscript of Zafar Nama in 1037 AH. / 1628 AD., Samarkand. This painting shows Amir Timur sitting on a hexagonal throne based on four legs. It is worth noting that this simple form of thrones evolved. Its edge was surrounded with a balustrade from all sides, except for the front side that was completely open. The back was high and ended with a lobbed arch whose top was decorated with a bird. This model appears in a painting entitled "The Shah and the Darwish" by Muhammed Sharif, Manuscript of Bustan Saadi in 1025 AH. / 1616 AD., Samarkand [7].

\subsubsection{The $2^{\text {nd }}$ model (the djawsaq)}

This model consists of two benches- one of them is larger. The four corners are topped by large marble columns to hold the wooden ceiling. These columns are modeled after the model dominating Central Asia. In front of the thrones, a staircase consists of three steps. This was the model of the Throne of Bukhara in the $13^{\text {th }} \mathrm{H}$. / $19^{\text {th }}$ G. century. Moreover, such thrones were furnished by the best types of carpet and embroidered silk cushions upon which the prince rested. Studying the paintings of the manuscripts of Central Asia shows that this model appeared in the school of Bukhara in the $9^{\text {th }}$ H. / $15^{\text {th }}$ G. century and continued in the $10^{\text {th }} \mathrm{H}$. / $16^{\text {th }} \mathrm{G}$. century. It is a square throne whose edge is surrounded, from three sides, with balustrades, and the fourth (front) side is incomplete. In front of the throne, there is a small stand (or footrest). In the four corners, high wooden pillars hold a wooden ceiling, fig. (11).

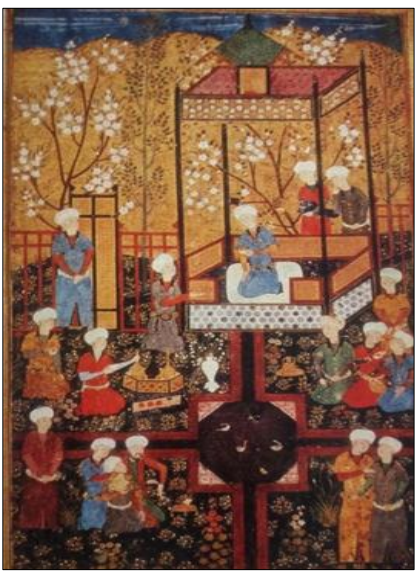

Figure (11) Shows a painting entitled "The Khan with his attendants and musicians" (After Пугаченкова, Миниатюры Средней Азии, 1979) 
This model appears in a painting entitled "An Old Man in the Presence of Sultan Hussein Mirza", Manuscript of five Nawai" at the Public Library of Saint Petersburg. Sometimes, a lantern covered with a pyramidal ceiling is depicted, such as a painting entitled "An Old Gladiator Beats his Young Apprentice", p.21, Manuscript of Bustan Saadi (891 AH. / 1486 AD.). It also appears in another painting entitled "King Saleh and the Two Poor Men", p.77, Manuscript of Bustan Saadi (938 AH. / 1532 AD.) and another painting of an Egyptian guest presenting the mirror of Prophet Joseph, p.31, Manuscript of Tuhfat Alahrar by Jami at the Public Library of Saint Petersburg $[9,10]$. In short, both models appeared in Central Asia from the Timurid Dynasty (the $8^{\text {th }} \mathrm{H}$. / $14^{\text {th }} \mathrm{G}$.) century to the $9^{\text {th }}-11^{\text {th }}$ H. $/ 15^{\text {th }}-17^{\text {th }}$ G. centuries. Some models date back to the $13^{\text {th }} \mathrm{H}$. / $19^{\text {th }}$ G. century during the Manghit era, such as the throne of Bukhara in Ark. Although the marble thrones dominated Central Asia till the $13^{\text {th }}$ H. $/ 19^{\text {th }}$ G. century, the wooden ones were introduced later in the century. These thrones were made of gilded and velvet-lined wood to be easily moved from a place to another. They were influenced by the Russian thrones in Saint Petersburg. For instance, the throne of Alim Khan (1328-1339 AH. / 1910-1920 AD.)- the last khan of Bukhara was wooden. Moreover, the throne of Muhammed Rahim Khan (1221-1241 AH. / 1806-1825 AD.) in Khiva was made of silver-coated and leather-lined wood, which is kept at the Museum of Weapons in Moscow. It has an inscription that reads "made in the reign of Muhammed Rahim Shah of Khwarazm in $1231 \mathrm{AH}$. / $1816 \mathrm{AD}$. by the humble Muhammed" [11,12].

\subsection{Raw material}

In the light of the samples under study, marble, especially white and grey, was the basic raw material in manufacturing the thrones of Central Asia. Marble was brought from the surrounding mountains, such as Gazgan Quarry in Nurata. Accordingly, there were some local engravers of stone and marble in Nurata [13]. The marble of Gazgan was well-known worldwide.
It was used in the furnishings of mosques and buildings of Bukhara and Samarkand. This marble is best known for its different colors, including blue, white, dark grey, and reddish. It can stand very low temperatures, as well [14]. The engravers of Bukhara used Gazgan marble to make artifacts related to architecture, e.g., bases of columns, statues, fountains, or applied artifacts, including engraved plates and pots. Although there were specialized engravers in Bukhara, the engravers of Nurata were recruited to make important marble artifacts because of their high skill [13].

\subsection{Methods of manufacturing and decoration}

When a throne was made, a big marble block was cut according to the desired size. It was cut, formed, engraved, and polished to be used in inscription and decoration. Therefore, engravers used many tools, such as chisels and hammers that fit the depth of engraving and the type of decoration. In Central Asia, relief engraving was known as "Khajmaley Oyma". This technique was used in making models, such as statues and big sculptures, which were made of stone, bone, wood, etc. [14]. It was also utilized in forming the different parts of the columns of thrones, including bases, bodies, and capitals. Specialists of marble engraving (Sangtarosh) implement decorations and inscriptions in high and base relief. Furthermore, the depth includes deep engraving "Chokor Oyma" and flat engraving "Yasi Oyma" of 1-1.5cm [14]. The paintings implemented on white marble artifacts were outlined with black paint to ensure their beauty and make them clearer when read from a distance [15].

\subsection{Decorative elements}

The decorative elements implemented on the marble thrones varied and included floral motifs, geometric shapes, inscriptions, and architectural elements.

\subsubsection{Floral motifs}

Engravers employed the modified floral motifs (islimi) with their various units, including wavy stems, flowers, six and multiplepetal flowers, triple leaves, feathered leaves, 
half-feathered leaves, half-palmettes, and buds in the different decorations of the surface of the marble thrones. They were major and subsidiary designs. *) Major designs: These decorative designs rely basically on the half-palmettes that occupy large parts of three major surface areas of the throne. 1) The first design took the form of stems of half-palmettes, forming bukhariyya-like oval shapes encompassing flowers. The ends of bukhariyyas are related together with a rhombus that encompasses a small rose and links the flowers and half-flowers in its upper and lower parts. This design was engraved on the sides of the lower bench of the Throne of Bukhara. 2 The second design took the form of overlapping stems, which end with half-palmettes, buds, feathered $s a z$ leaves, triple leaves, flowers, and six-petal small roses. It occupies the body of the back columns of the Throne of Bukhara, fig. (12).

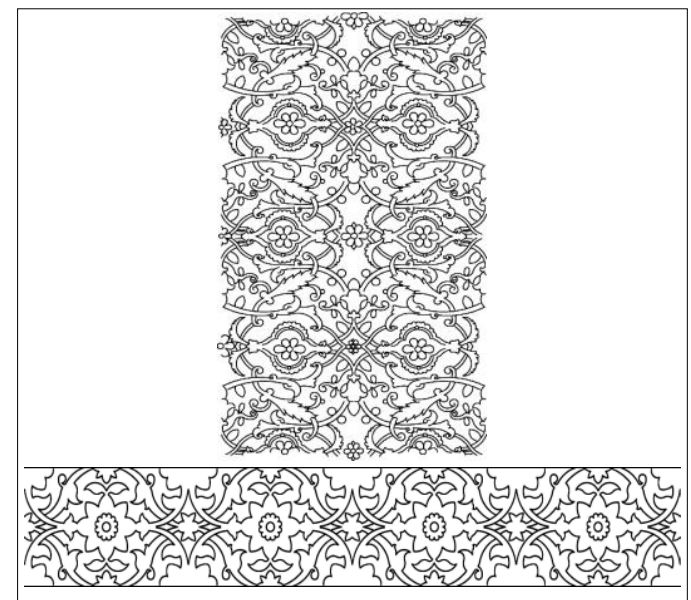

Figure (12) Shows major floral designs on the throne of Bukhara

3) The third design consisted of modified floral motifs ending with half-palmettes and leaves. It was implemented on the bench of Kök Tash in Samarkand and the pear-like part of the back columns of the throne of Bukhara. *) Subsidiary designs: These designs occupied the narrow frames around the major designs. They included one wavy stem or two of half-palmettes on the two narrow frames on both sides of the bench of the throne or the narrow frame around the façades of the first step of the staircase, fig. (13). They might also contain two wavy and interrelated stems. While one stem was half-palmettes, the other was made of flowers and small roses. These figures were implemented on the square bases of the columns of the throne of Bukhara.

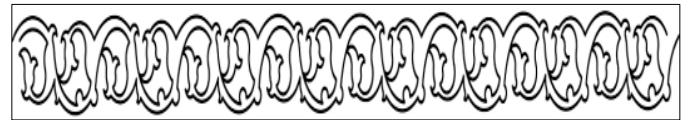

Figure (13) Shows subsidiary floral designs on the throne of Bukhara

\subsubsection{Geometric figures}

The marble throne in Bukhara was decorated with composite and intricate geometric figures (girikh), which were based on hexagonal shapes encompassing stars and other shapes, fig. (14-a). They also included simple shapes, e.g. lines, right and helical ribs, triangles, etc. Frames of writing and quadrilateral medallions were also used, fig. (14-b). On the contrary, the decoration of the composite columns of the Throne of Samarkand was limited to helical shapes.

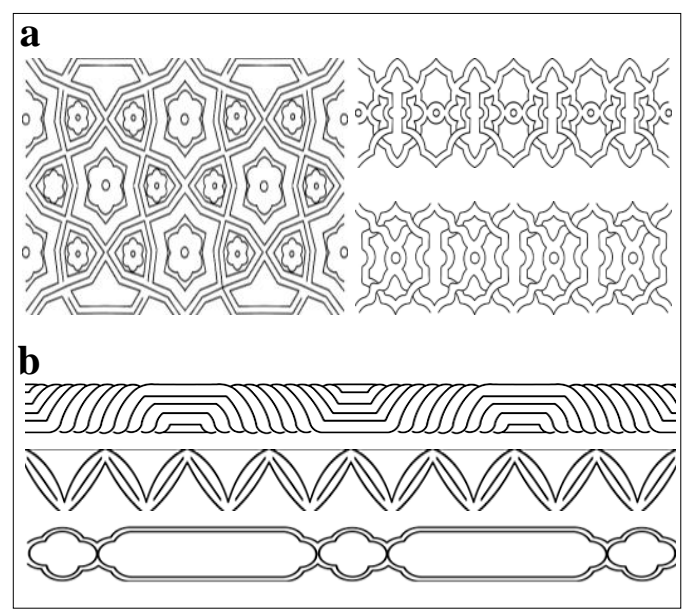

Figure (14) Shows a. composite geometric shapes, b. simple geometric shapes on the throne of Bukhara

\subsubsection{Inscriptions}

In terms of form, the decorative items on the marble throne of Bukhara included inscriptions in Tajik Persian. They were lines of poetry with a literary and registration content implemented in the Nastaliq script on the bench and columns because Persian was one of the local languages but was later replaced with Turkish due to the influence of the Turkish tribes. However, the speakers of Persian maintained their lang- 
uage and cultural background. Many rulers, such as the Timurid dynasty tended to the Islamic Persian culture and had buildings modeled after the Persian style [16]. The Tajik inhabitants played a considerable role in the dissemination of the Persian language and culture in Bukhara, Samarkand, and other cities in Central Asia.

In terms of content, the lines of poetry included literary pieces to describe the throne, as well as its location and beauty. For example, the throne was described as a garden that has two cypresses. The columns were described as a garden containing two high green palm trees and two willows of thin stature that Allah created for good luck. In addition, the registration content of the lines included some names, titles, and dates. *) Names: The inscriptions of the throne contained some names of buildings, e.g. palaces, and countries. For example, the throne was made to decorate the reception hall "كورنيش خانة of the "Palace of Justice" "قصر عدالت", which was dedicated to receiving envoys, holding official events, and issuing judicial judgments. Moreover, the throne was made to renew "the palace of luck and attendance" "قصر بخت و إقبال" that may be another title or attribute of the palace. It is worth noting that the throne was not made during establishing the palace but at the time of renewal, fig. (15-a). To refer to the country, the old name of Transoxiana, i.e. the Kingdom of Turan "دار الملكتوران", was used [17], fig. (15-b). It is worth mentioning that this proper name appeared in the inscriptions of the architectural and applied arts in Central Asia for the first time. *) Titles: The inscriptions of the throne contained some titles of the ruling prince or khan in Bukhara, such as Nasiru-dawla wa-ddin"كامكار دولت ودين", mohetul-elm, and saheb-ul-kamal" محيط دانش "صاحب كمالى . To the author's knowledge, these titles appeared for the first time on this throne. The religious titles, including Nasir-u-ddin, were not registered on the coins of khans in Central Asia during the
Ashtarkhanid (1006-1157 AH. / 1597-1744 AD.) or the Manghit dynasties (1160- 1339 AH. / 1747-1920 AD.), fig. (15-c). It is worth noting that the inscriptions of the throne suggested that it was made in the reign of Nasir-u-dawla wa-ddin, mohetul-elm, and saheb-ul-kamal without stating the name of the owner. Although no signature of the manufacturer was inserted on the throne, some titles referred to him, such as alostazwa-saheb-ul-funon (master of arts) that was written as"مهيا ساخت استاد هنرور". Alostaz suggested his skill, mastery, and proficiency, while saheb-ul-funon indicated that he mastered more than one art, fig. (15-c). *) Dates: The inscriptions included lines of poetry, which ended with the date of manufacturing the throne using the letters of the alphabet. The lines suggested two different dates as "به يك مصر عو تأريخ مسلم". تأريخ "Also, the date was reported in two parts "او بي كسر ونقصان and "تأريخش رقم شد", fig. (15-d): Calculating both dates using the letters of the alphabet shows that the throne was manufactured in $1249 \mathrm{AH}$. I 1833 AD. during the reign of Amir Nasr Allah Khan ibn Amir Haidar who became the ruler of Bukhara in 1242 AH. / 1827 AD. and died in 1277 AH. / $1860 \mathrm{AD}$. as he ruled thirty-five years and some months [18]. The throne might be made because Amir Nasr Allah wanted to have a throne in the Palace of Bukhara that paralleled that of Samarkand. Thus, the coronation was on both thrones; the throne of Samarkand because it was important for the legitimacy of the throne and the throne of Bukhara because it was the capital, the place of receiving foreign envoys, and other issues. The oldest date using the letters of the alphabet in the region was inserted in the early $8^{\text {th }} \mathrm{H}$. / $14^{\text {th }} \mathrm{G}$. century in the structure of Aladdin Cobra in $702 \mathrm{AH}$. I 1302 AD. However, this method was not common in Central Asia before the $11^{\text {th }}$ H./17 $7^{\text {th }}$ G. century. The school of "Khawajem Bardy Bey" was one of the earliest buildings on which dates were inserted using the letters of the alphabet in Khanate of Khiva [19]. 


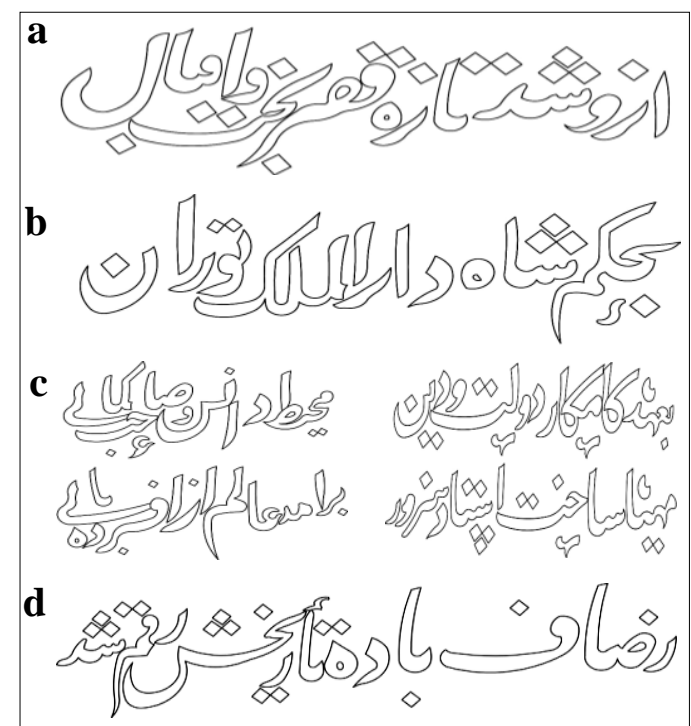

Figure (15) Shows $\underline{\text { a. }}$ the name of "the palace of luck and attendance" on the throne of Bukhara, $\underline{\mathbf{b}}$. the name of the kingdom of Turan on the throne of Bukhara, c. titles on the throne of Bukhara, d. date inserted using the letters of the alphabet on the throne of Bukhara

\subsubsection{Architectural items}

*) Stalactites: These architectural items played a major role in some buildings. They also fulfilled the function of a decorative unit. The engravers of Bukhara used the stalactite as a basic item in engraving and forming the capitals of the main columns and decorating the edges of bases and benches of the Throne of Bukhara. Stalactites were basic items in forming the models of wooden capitals in the buildings of Bukhara in the $12^{\text {th }}-13^{\text {th }} \mathrm{H}$. $/ 18^{\text {th }}-19^{\text {th }} \mathrm{G}$. centuries, such as the wooden columns of Subhan Quli Khan Mosque in 1111-1123 AH./1700-1712AD, fig. (16-a). *)Columns: They were used as a main architectural element for holding the wooden ceiling that covered the Throne of Bukhara. Engravers used them as a decorative item to decorate the sides of the Throne of Samarkand. Moreover, using side columns spread in the decoration of marble, stone, and ceramic structures and coffins in Central Asia. *) Machicoulises: Their forms were included in the decorative items used to decorate the Throne of Bukhara. They took the form of a row of up and down triple-leaves (madokhil) occupying the bases of the marble columns on both sides of the throne, fig. (16-b). They were also used to decorate various artifacts made of wood, stone, stucco, and others in Bukhara in the $13^{\text {th }} \mathrm{H}$. / $19^{\text {th }} \mathrm{G}$. and early $14^{\text {th }} \mathrm{H}$. / $20^{\text {th }} \mathrm{G}$. centuries.

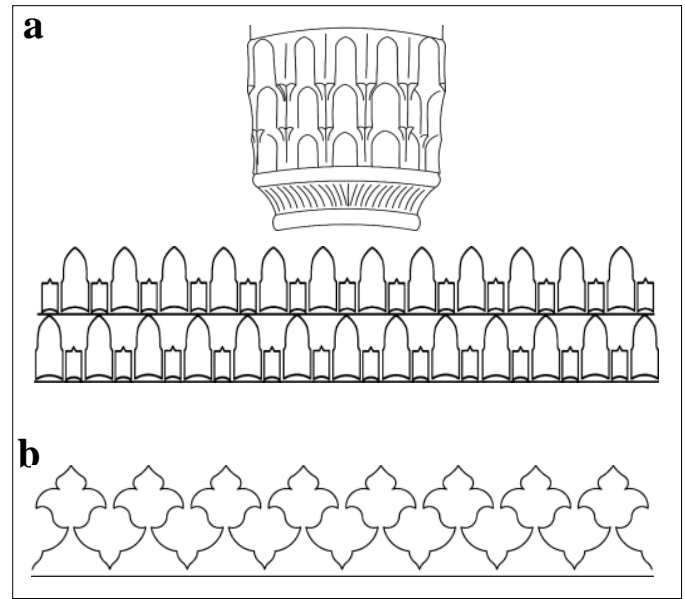

Figure (16) Shows a. stalactites on the mastaba (bench) and columns of the throne of Bukhara, $\underline{\mathbf{b}}$. machicoulises in the form of triple leaves on the throne of Bukhara

\section{Results}

1.Two marble thrones remained in Bukhara and Samarkand. The oldest is the throne of Kök Tash in Samarkand dating back to the early Timurid period, and the other is the Throne of Ark in Bukhara in the $13^{\text {th }} \mathrm{H}$. / $19^{\text {th }} \mathrm{G}$. century.

2. In the light of the remaining models in Bukhara and Samarkand and the paintings of manuscripts, the marble thrones are classified in terms of form into two models: The Mastaba (bench) and the Djawsaq.

3.In the light of the models under study, the remaining thrones were made of white and grey marble from Gazgan Quarry in Nurata. Their decorations were mainly implemented in high and base relief.

4. While the throne of Kök Tash in Samarkand was decorated with floral motifs, the throne of Bukhara contained floral motifs, geometric shapes, architectural elements, and inscriptions.

5. The inscriptions of the throne of Bukhara in Ark were in Tajik Persian using the Nastaliq script that was used for implementing most inscriptions of architecture and arts in Central Asia in the $13^{\text {th }} \mathrm{H}$. / $19^{\text {th }}$ G. century. 
6. The inscriptions of the throne of Bukhara comprised Persian poetry with a literary content to describe and praise the throne and a registration content of names, titles, and dates.

7. To the author's knowledge, The Kingdom of Turan -the old name of Transoxianaappeared on the architectural and applied arts in Central Asia for the first time.

8. The inscriptions included some honorary titles that appeared for the first time in Central Asia, such as Nasir-u-dawla wa-ddin, mohet-ul-elm, and saheb-ulkamal. Although these inscriptions did not indicate the name of the throne's owner, they helped identify some titles of Bukhara's Khan Nasr Allah.

9. The date was inserted on the throne of Bukhara using the letters of the alphabet (words) not mere numbers or letters. For the first time, the date was separated into two parts, including 1249 AH./ 1833 AD.- the date of manufacturing the throne in the reign of Bukhara's Khan Nasr Allah.

\section{Discussion}

The study of Ron Sela pioneered exploring the marble stone Kök Tash in Samarkand, tracking the historical resources. However, it neglected the artistic aspect. The present study is interested in the development of the shapes and models of marble stones in Bukhara and Samarkand from the Timurid Era to the late Manghit Era in the light of the remaining models. It also compares the artistic aspect. The former study overlooked comparing Kök Tash in Samarkand to the contemporary manuscripts in Central Asia that illustrated two models of thrones in the Timurid period. Sela presented various perspectives on the place of bringing the marble stones of making Kök Tash. The study agrees with the argument that the stone used was brought from a local quarry in Central Asia, i.e. the well-known quarry of Gazgan.

\section{Conclusion}

The present study highlighted the importance of thrones for princes and khans in Western Turkestan or Central Asia because they were interested in having them in their palaces from the reign of Amir Timur to the Russian occupation. These thrones were decorated with the distinctive styles of the Uzbek artifacts of the time. They also showed the mastery and skill of manufacturers in making masterpieces that have remained. Moreover, the study helped identify the architecture, arts, civilization, culture, and language of Central Asia. Further studies should be conducted to investigate this important region.

\section{References}

[1]Зохидов, П.Ш. (1996). Меьмор олами (Architectural world), комуслар Бош taxририяти, Тошкент.

[2] Sela, R. (2007). The "heavenly stone" (Kök Tash) of Samarkand: A rebel's narrative transformed, $J$. of the Royal Asiatic Society, Vol. 17, (1), pp: 21-32.

[3] Schuyler, E. (1877). Turkistan, Notes of a journey in Russian Turkistan, Kokand, Bukhara and Kuldja, Vol.1, Scribner, Armstrong \& Co, NY.

[4] Skrine, F. \& Ross, E. (1973). The heart of Asia, Arno Press, NY.

[5] Naumkin, V. (1995). Samarkand, AlMugam Al-thaqafy, Abu Dhabi.

[6] Arapov, A. (2006). Masterpieces of central Asia, Bukhara, SAN'AT press, Tashkent.

[7]Пугаченкова, Г. \& Галеркина, О. (1979). Миниатюры средней азии (Miniatures of Central Asia), Изобразителное Искусство, Москва.

[8] Pugachenkova, G. (1994). Miniatures of central Asia, Sharq, Tashkent.

[9] Gaber, M. (2005). Madraset Bukhara fe al-tasweer al-Islamy khilal al-qarn al-asher al-hejri (Bukhara school in Islamic painting in the tenth hijri century), MA., Islamic Archaeology dept., Faculty of Archeology, Cairo Univ.

[10] Пугаченкова, Г. \& Ремпель, Л. (1960). Выдающиеся памяаники изобразительного искусства узбекистана (Monuments of fine art of Uzbekistan), State Literature Pub. House of Uzbekistan, Ташкент.

[11] Madamino, M., Masharipov, B., \& Abdurasulov, A., (2001). Khiva, Guide Book, RUZ Co Pub., Moscow. 
[12] Howorth, H. (1889). History of the Mongols from the $9^{\text {th }}$ to the $19^{\text {th }}$ centuries, Part II, Longmans, Green \& Co., London.

[13] Akilova, N. (1999). Stone carving, in: Khakimov, A. (ed.) Atlas of central Asian artistic crafts and trades, Vol. I, International Institute for Central Asian Studies Samarkand, Uzbekistan, Sharq, Tashkent, pp: 43-44.

[14] Булатов, С. (1991). Узбекхалк амалий безак санъати (Folk applied art of Uzbek), Мехнат, Тошкент).

[15] Abdullaev, M. (2011). Carved marble, San'at, Vol. 3, pp. 12-13.
[16] Luijendijk, D. (2016). Pahlavan Mahmud of Khiva, Iran and Caucasus, Vol. 20, pp: 1-15.

[17] Al-Hamawy, Y. (1993). Mu'gam albildan (Dictionary of countries), Vol. 2, Dar Sadir, Beirut.

[18] Al-Terazy, N. (2010). Turkistan, madyha wa hadereha (Turkistan, the past and the present), $1^{\text {st }}$ ed., Maktabit Al-Adab, Cairo.

[19] Sowailim, A. \& Abeed, S. (2015). Persian inscriptions on religious buildings in Khania "Khiwa" in the $12-13^{\text {th }} \mathrm{H} / 18-19^{\text {th }}$ G. Centuries: A Study of the Form and the Content, Arab J. for the Humanities, Vol. 130/ 33, pp. 83-121. 